\title{
Impactos dos Acordos de Liberalização Comercial Alca e Mercoeuro sobre os Países Membros*
}

\author{
Ângelo Costa Gurgel** \\ Mayra Batista Bitencourt*** \\ Erly Cardoso Teixeira***
}

Sumário: 1. Introdução; 2. Dados, modelos, simulações e software; 3. Resultados; 4. Conclusão.

Palavras-chave: equilíbrio geral; comércio internacional; blocos econômicos.

Códigos JEL: F15; Q17; C68.

O objetivo deste trabalho é determinar os impactos da formação da Alca e de um possível bloco de comércio do Mercosul com a União Européia, para o Brasil em particular e para os demais países envolvidos em tais blocos, enfatizando os efeitos sobre o setor agrícola. O modelo de equilíbrio geral aplicado do Projeto de Análise de Comércio Global (Gtap) é usado para implementar as simulações. Os resultados sugerem que a Alca traz aumentos na produção agrícola e superávits comerciais nos países do Mercosul; no entanto, para os produtos manufaturados tais efeitos são negativos. Os EUA e o Canadá apresentam uma pequena redução na balança comercial. O Brasil é o único país do Mercosul com ganhos de bem-estar. Os efeitos do Mercoeuro sobre os países membros são similares aos da Alca, porém em maior magnitude. Os ganhos de bem-estar estão presentes para todos os países do Mercoeuro, sendo este acordo mais favorável para os países do Mercosul do que a Alca.

The objective of this paper is to determine the impacts on the international agricultural market of potential trade liberalization agreements such as Americas Free Trade Area (Afta) and Mercosul and European Union Free Trade Area (Mercoeuro). The general equilibrium model from the Global Trade Analysis Project (Gtap) is applied to run the simulations. The results suggest that Afta increases agricultural production and trade balance for the Mercosul countries, but for manufactures the effects are negative on both production and trade balance. The U.S. and Canada show a small reduction on trade balance. Brazil is the only Mercosul country to obtain welfare gains with Afta. The impacts of Mercoeuro on its member country are similar to those of Afta, but they are greater in magnitude. Also, all countries have welfare gains in the Mercoeuro, which presents greater benefits than Afta to their respective.

\footnotetext{
* Artigo recebido em abr. 2000 e aprovado em jan. 2001.

** Engenheiro agrônomo e doutorando em economia rural pela Universidade Federal de Viçosa $(U F V)$.

*** Economista e doutoranda em economia rural pela UFV.

*** Professor titular do Departamento de Economia Rural da UFV.
} 


\section{Introdução}

O comércio internacional tem-se intensificado no mundo inteiro, como resultado das negociações ocorridas no âmbito da Rodada Uruguai do Gatt, bem como na ascensão e intensificação dos blocos de comércio entre países geograficamente próximos, como o Mercosul. Dessa forma, novas possibilidades de intensificação de comércio são vislumbradas pelo Brasil com a formação da Área de Livre Comércio das Américas (Alca) e a possibilidade de acordos com a União Européia (UE).

Os impactos de tais acordos, tanto daqueles já firmados como daqueles em discussão, sobre o Brasil e demais países do Mercosul ainda não são de todo conhecidos. O estudo de tais impactos torna-se importante para auxiliar o processo de negociação, de forma a identificar quais os possíveis ganhos não apenas em forma de comércio, mas também na forma de geração de bem-estar social e crescimento econômico. Assim, o objetivo deste artigo é determinar os impactos advindos da formação da Alca e de um possível bloco de comércio com a União Européia (Mercoeuro), para o Brasil em particular e para os demais países envolvidos em tais blocos, enfatizando os efeitos sobre o setor agrícola. Consideram-se aqueles efeitos advindos dos acordos já firmados na Rodada Uruguai e no Mercosul.

As negociações para a formação da Área de Livre Comércio das Américas (Alca) começaram em 1994, com a finalidade de expandir acordos como o Nafta e o Mercosul para os 34 países do continente americano, exceto Cuba. Além dos aspectos econômicos e comerciais, aspectos políticos, sociais e ambientais foram contemplados, de forma a possibilitar o desenvolvimento dos países da América Latina.

Nas negociações da Alca têm ocorrido posições divergentes defendidas pelo Brasil e pelos EUA. Os EUA defendem a implementação de um cronograma de liberalização comercial mais abrangente e realizado de forma mais rápida. Para o Brasil e demais países da América Latina a integração do comércio nas Américas deve ser mais lenta, de forma a permitir ajustamentos nestes países frente à maior potência comercial do mundo, os EUA. Como discutido por Abreu (1995), para o Brasil a liberação de comércio através da eliminação de tarifas poderia deixar a economia muito exposta à concorrência internacional, enquanto os ganhos que o país poderia obter estariam relacionados com o acesso a determinados mercados, como o de suco de laranja, os quais não sofreriam redução atisfatória de barreiras por parte dos EUA no curto prazo. 
Diante destas questões, a negociação de uma área de tarifa zero está programada para começar em 2005. Para isso, muitos países já estão procurando fazer ajustes nesta direção, reduzindo taxa de juros, impostos e tarifas, procurando melhorar a competitividade de suas indústrias. A análise dos possíveis impactos advindos da Alca auxilia no entendimento e na elaboração de recomendações quanto à este processo.

O estreitamento das relações comerciais entre os países do Mercosul e o bloco da União Européia tem sido discutido recentemente, sendo considerado uma área promissora para acordos comerciais. A I Cimeira dos Chefes de Estado e de Governo da União Européia, América Latina e Caribe, realizada no Rio de Janeiro em 1999, pode ter sido o ponto de partida para tais acordos. Cabe ressaltar que a cimeira envolveu todos os países da América Latina, Caribe e a União Européia, com o intuito de aproximar as relações comerciais entre os continentes. O potencial de redução de barreiras ao comércio entre estes parece ser imenso. Sendo este assunto muito recente e mais distante da realidade atual que a Alca, deve-se considerar que não existem metas claras para a redução de tarifas e subsídios, cabendo, portanto, a suposição quanto aos possíveis valores a serem negociados e o estudo dos impactos daí gerados.

A teoria tarifária prevê que, para os países de pequenas economias, qualquer nível tarifário tende a reduzir o bem-estar doméstico. Por outro lado, os países de grandes economias podem ser melhorados com aplicações de tarifas, que gerariam aumentos no bem-estar, quando a receita tarifária fosse maior do que as perdas sociais (tarifa ótima) (Helpman \& Krugman, 1989).

A teoria de comércio internacional sugere que a formação de uma área de livre comércio melhora o bem-estar da população do país se o volume total de comércio crescer em todos os países do bloco, isto é, se a criação de comércio exceder o desvio de comércio para países não-membros. Segundo Teixeira (1998), citando Robinson e De Rosa (1995), haverá criação de comércio se o aumento do volume total deste, dentro do bloco econômico, for maior que a redução do comércio com países não-membros. Vale ressaltar que não necessariamente o comércio entre os países do bloco e fora dele deverá apresentar redução; caso ocorra aumento no fluxo comercial entre os mesmos, maior será o grau de criação de comércio.

Valverde e Teixeira (1997), utilizando o modelo Gtap e sua base de dados, segunda versão, discutem o possível impacto da Alca no mercado internacional. Os resultados para o Brasil sugerem que a Alca tem um pequeno impacto, mas positivo, em todos os indicadores econômicos. 
Carvalho e Parente (1999), utilizando um modelo de equilíbrio parcial para analisar os possíveis efeitos da Alca sobre o Brasil, encontram que o aumento no volume das importações seria consideravelmente superior aos aumentos das exportações. Concluem que a participação dos EUA na Alca reduz os ganhos de comércio dos demais parceiros, por se tratar da maior potência mundial e do país com maiores ganhos de competitividade. Porém, a metodologia utilizada de equilíbrio parcial não permite medir impactos sobre produção, emprego, bem-estar e outros indicadores relevantes.

Este artigo pretende analisar a questão da integração econômica do Mercosul com a Alca e com a União Européia, utilizando uma estrutura de equilíbrio geral, a partir do modelo Gtap e do seu banco de dados na terceira versão. Dessa forma, procura inovar ao utilizar uma versão mais atualizada do banco de dados e ao discutir a implementação de um acordo com a União Européia. Seguem-se as considerações metodológicas, de dados, modelo, simulações e software usado para implementar o modelo Gtap. Após, vêm as discussões dos resultados e as conclusões.

\section{Modelo Gtap}

Os modelos de equilíbrio geral (CEG) analisam todos os mercados em conjunto, bem como as influências que exercem uns sobre os outros, sendo apropriado, portanto, para o tipo de estudo proposto. Neste artigo o modelo CEG utilizado será o Gtap (Global Trade Analysis Project), por compreender vários países e ser capaz de avaliar as reformas de comércio multilateral, ou seja, ideal para as análises relativas à integração regional. Este modelo foi desenvolvido por Hertel e Tsigas (1997), sendo coordenado pelo Centro de Análise de Comércio Global do Departamento de Economia Agrícola da Universidade de Purdue.

O Gtap ${ }^{1}$ é composto por um modelo completo de equilíbrio geral para o comércio internacional. Possui uma ampla base de dados, referentes a 30 países e 37 commodities (tabela 1). Para executar o programa, utiliza-se o software Gempack, desenvolvido por Codsi e Pearson (1988).

A agregação utilizada é a 3.16, contendo nove setores e 10 países (tabela 1). Serão analisados os efeitos sobre os países da América e para a União Européia. Dessa forma, a agregação 3.16 permite visualizar os resultados simulados para

\footnotetext{
${ }^{1}$ As informações sobre o Gtap são baseadas em Hertel (1997).
} 
o Brasil, Argentina e Chile (que representam o Mercosul), Canadá, EUA, México, demais países da América Latina (agregados como a região LAM) e, ainda, a União Européia.

No que tange ao banco de dados, estes refletem o ambiente econômico de 1992. De acordo com Gehlhar e outros autores (1996), nem todos os países têm seus dados explicitados na base do Gtap. Por esse motivo, a estratégia adotada é a da elaboração de matrizes insumo-produto por regiões, utilizandose conceitos contábeis previamente definidos. No caso do Brasil, a matriz de insumo-produto é de 1980, sendo atualizada, através da taxa de câmbio, para o ambiente econômico de 1992. As taxações/subsídios à produção e à exportação se referem ao período de 1986-88. Os dados de tarifas à importação dizem respeito ao ano de 1994, já incluindo, portanto, as negociações da OMC.

Uma idéia do funcionamento da economia, numa visão geral do Gtap, está representada na figura $1,{ }^{2}$ que mostra as inter-relações dos agentes do modelo.

Ao iniciar a descrição pela despesa do agente regional (figura 1), constatase que esta é determinada por uma função de utilidade agregada, por meio da qual as despesas são alocadas entre consumo privado (PRIVEXP), consumo do governo $(G O V E X P)$ e poupança global $(S A V E)$. A fonte de receita para o agente regional é dada pela venda das commodities, aqui representada por $V O A$ (valor do produto, a preços de agente) e pelos impostos, TAXES (incididos sobre os produtos domésticos), MTAX (tarifas à importação) e XTAX (taxas à exportação).

Quanto aos produtores, verifica-se que as receitas são obtidas por meio das vendas de sua produção aos agentes domésticos, que são o governo (VDGA, valor das compras domésticas pelo governo, a preços de mercado), agentes privados ( $V D P A)$, valor das compras domésticas, pelo setor privado a preços de agente e outras firmas ( $V D F A$, consumo intermediário), e aos agentes externos (resto do mundo, que representa a fonte de importação e o destino das exportações), por meio das exportações ( $V X M D)$. Similarmente, os produtores gastam suas receitas no consumo intermediário ( $V D F A)$, nos fatores primários (VDPA), nas importações (VIFA), bem como em impostos (TAXES), que são pagos ao governo. Dessa forma, toda receita gerada pelos produtores é despendida em despesas com as compras de fatores intermediários e serviços de fatores primários, dando, portanto, a condição de lucro zero (pressuposição do fechamento).

\footnotetext{
${ }^{2}$ Esta figura, bem como sua explicação, está baseada em Ferreira Filho (1998) e Hertel (1997).
} 
Tabela 1

Agregação de commodities e regiões

\begin{tabular}{l}
\hline Agregação regional \\
\hline 1. Resto do mundo (ROW) - Austrália, \\
Nova Zelândia, Japão, República da \\
Coréia, Indonésia, Malásia, Filipinas, \\
Cingapura, Tailândia, China, Hong \\
Kong, Taiwan, Índia, resto do Sul da \\
Ásia, ex-União Soviética, Meio-Oeste \\
e Norte de África, África subsaariana, \\
todo os outros países. \\
2. Canada (CAN). \\
3. Estados Unidos da América (EUA). \\
4. México (MEX). \\
5. Resto da América Latina (LAM) - \\
América Central e Caribe e resto da \\
América do Sul. \\
6. Argentina (ARG).
\end{tabular}

7. Brasil (BRA).

8. Chile (CHI).

9. União Européia 12 (EU).

10. Resto da Europa (REU) - Áustria, Finlândia e Suíça; Associação da Europa Central e Área de livre comércio da Europa.
Agregação de commodities

2. Trigo

3. Outros grãos.

4. Outras culturas.

5. Produtos animais - lã, outros produtos animais.

6. Produtos florestais - madeira serrada, pasta de papel e outros produtos florestais.

7. Alimentos - produtos de pesca, arroz processado, carnes, leite e derivados, outros produtos alimentares, bebida e fumo.

8. Manufaturas - carvão vegetal, óleo, gás, outros minerais, têxteis, vestuário, couro, petróleo e carvão, química, borracha e plásticos, minerais não-metálico, metais ferrosos primários, metais não-ferrosos, produtos de metal, indústria de transporte, equipamentos e maquinário, outros produtos manufaturados.

9. Serviços - eletricidade, água e gás, construção, comércio e transporte, outros serviços (privado), outros serviços (governamental) e habitação. 
Figura I

\section{Eeonomia multirregional aberta}

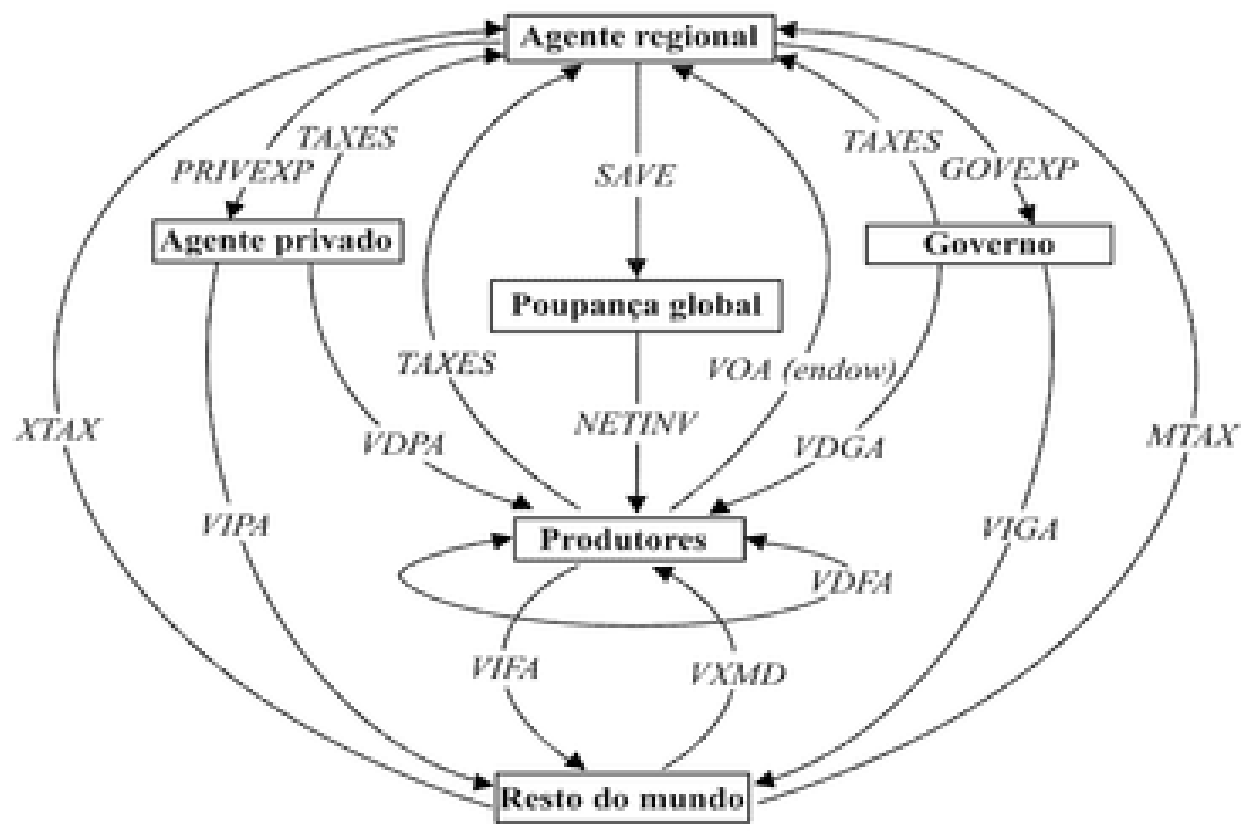

Fonte: Hertel (1997).

O governo e os agentes privados gastam suas rendas em produtos domésticos e importados (VIPA, para agentes privados; VIGA, para governo). Da mesma forma, ambos os agentes pagam impostos de importação (MTAX) e de consumo (TAXES) e poupam ( $S A V E)$. Os fluxos regionais de poupança são agregados em nível global, poupança global, que são, posteriormente, distribuídos para investimento em cada região.

Ás relações entre os agentes econômicos são expressas pelos valores, mas sua representação em mudanças percentuais nos preços e nas quantidades é mais atrativa. Dessa forma, os métodos de resolução matemática utilizados pelo Gtap são sistemas linearizados. A representação linear deste modelo, quando efetuada pelo método de Johansen, é criticada por conduzir, quando sujeita a choque, a uma solução muito afastada da que seria obtida pela divisão do choque em sucessivos pequenos choques, fazendo com que a precisão se eleve e aproxime da representação não linear. A natureza dessa crítica pode ser melhor entendida na Figura 2. 
Figura 2

O método de Euler

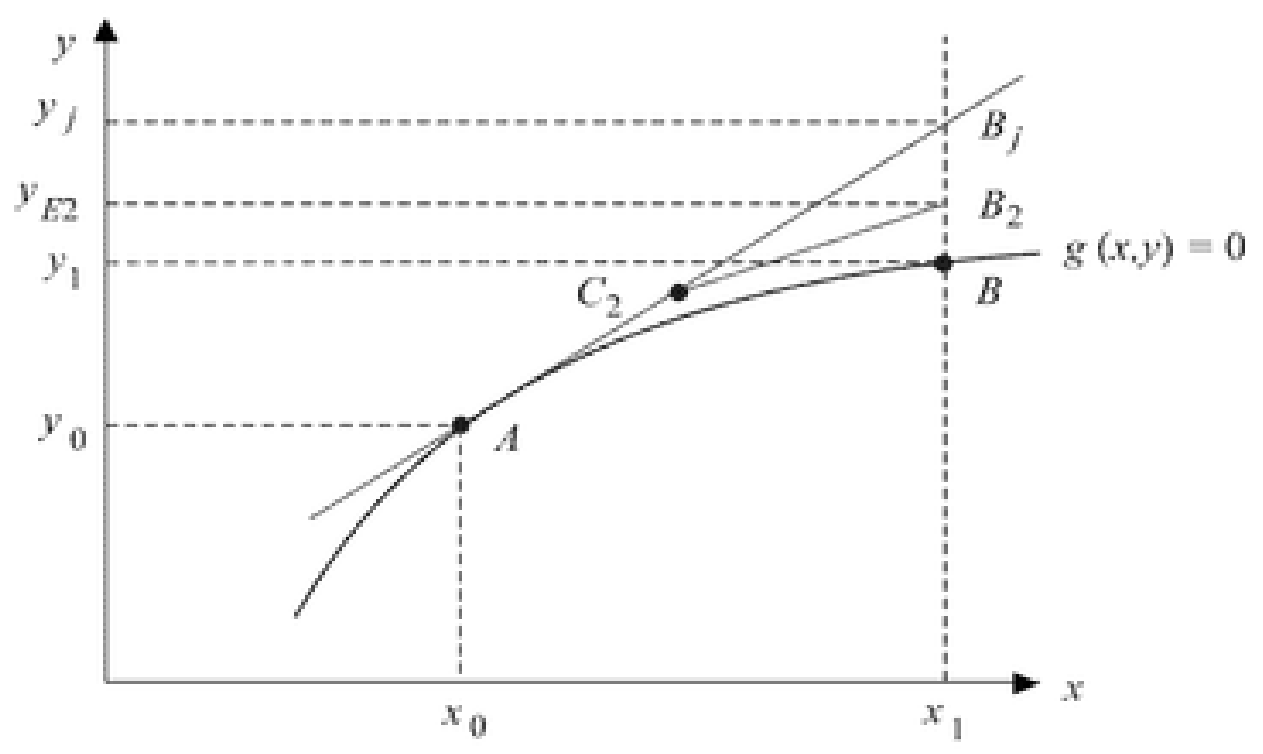

Fonte: Hertel (1997).

A figura 2 mostra uma exposição gráfica do método de resolução de um modelo não-linear, mediante uma representação linearizada. Com fins de simplificação, o modelo completo é dado por uma equação simples $\mathrm{g}(\mathrm{x}, \mathrm{y})=0$, em que a variável $\mathrm{X}$ é exógena e a variável $\mathrm{Y}$ é endógena. O equilíbrio inicial é representado pelos pontos $\left(X_{0}, Y_{0}\right)$. Ao alterar o valor da variável exógena $X_{0}$ para $X_{1}$, o resultado da variável endógena seria um novo nível $Y_{1}$. Se, entretanto, a variação fosse calculada pela representação linear simples do modelo em $\left(X_{0}, Y_{0}\right)$, o resultado seria $B_{j}=\left(X_{1}, Y_{j}\right)$, que é a conhecida aproximação de Johansen, e geraria um resultado obviamente errado, uma vez que $Y_{j}>Y_{1}$. O método de Johansen, portanto, calcula $\partial x / \partial y$ no ponto $A$, ou seja, move-se, ao longo da tangente, à curva no ponto $A$.

Verifica-se, entretanto, que a precisão do método pode ser consideravelmente melhorada, dividindo-se em partes a variação inicial na variável exógena $X$ e recalculando-se o novo equilíbrio a partir de cada uma dessas variações menores. Este método levaria à solução sucessiva do ponto $A$ para o ponto $C_{2}$ e $B_{2}$. Este é o método de Euler para solução de sistemas via representação linear. Ao aumentar-se, adequadamente, o número de passos intermediários 
do método, obtêm-se soluções cada vez mais acuradas. Por meio do software Gempack, é possível, por aproximações sucessivas, dar resultado equivalente dos métodos não-lineares de solução, utilizando-se o método de Gragg, que permite especificar maior número de passos em comparação com o método de Euler; portanto, tem-se uma solução acurada do sistema.

\subsection{Comportamento e relações econômicas dos agentes}

Iniciando pelo comportamento da firma, a figura 3 exibe a tecnologia utilizada pelas firmas em cada uma das indústrias do modelo, sintetizada na árvore tecnológica ou de produção. Esta árvore consiste num meio conveniente de representação de tecnologias separáveis e com retornos constantes.

\section{Figura 3}

Estrutura de produção

\section{Árvore tecnológica do GTAP}

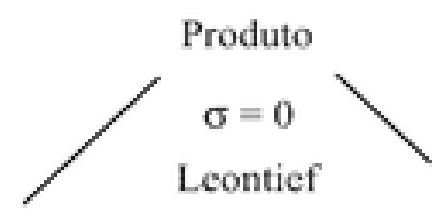

Valor adicionado

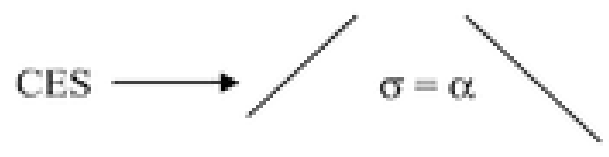

Terra Trabalho Capital
Insumos

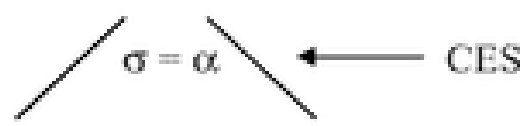

Domésticos Importados

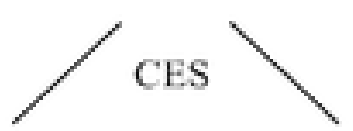

Origens

Fonte: Hertel (1997). 
A combinação de insumos usada pela firma na produção de seu produto, $Q O(i, s)$, depende das pressuposições adotadas acerca da separabilidade na produção. Nesse caso, admite-se que a firma escolha o mix ótimo de fatores primários, independentemente dos preços dos insumos intermediários. Com essa pressuposição de separabilidade, está-se impondo que a elasticidade de substituição entre qualquer fator primário individual, de um lado, e insumos intermediários, de outro, seja igual. É isso que possibilita a obtenção da árvore de produção, dado que sua elasticidade comum permite traçar o primeiro nó da árvore, onde insumos intermediários e fatores primários são combinados. Dentro do nested de fatores primários, as possibilidades de substituição reduzem-se a um único parâmetro, ou seja, admite-se uma função do tipo CES, que pode ser apresentada da seguinte forma:

$$
Q=A\left[\delta K^{-\rho}+(1-\delta) L^{-\rho}\right]^{-1}, \text { em que } A>0 ; \quad 0<\delta<1 ; \quad \rho>-1
$$

em que $Q$ representa a quantidade produzida; $K$ (capital) e $L$ (trabalho) são fatores de produção; $A$ é um parâmetro de eficiência e pode ser entendido como um indicador do estado da tecnologia; $\delta$ é um parâmetro de distribuição que se relaciona com as participações relativas dos fatores no produto; e $\rho$ é o parâmetro de substituição que determina o valor constante da elasticidade de substituição para funções dessa natureza.

Assim, em funções do tipo CES, que possuem elasticidade de substituição constante e diferente da unidade, mudanças percentuais na relação de preços, independentemente de suas magnitudes, refletem sempre na mesma proporção, na substitubilidade dos bens ou fatores. A partir da equação (1) é possível calcular a elasticidade de substituição, que será igual a:

$$
\sigma=1 /(1+\rho)
$$

Substituindo-se (2) em (1), obtém-se a seguinte expressão simplificada:

$$
Q=A\left[\delta K^{(\sigma-1) / \sigma}+(1-\delta) L^{(\sigma-1) / \sigma}\right]^{\sigma /(\sigma-1)}
$$

Essa pressuposição, com a inclusão do fator primário terra, para o caso da agricultura, requer apenas que todas as elasticidades de substituição entre os pares de fatores sejam iguais. O fator terra é empregado apenas na atividade agrícola e é imperfeitamente móvel entre setores. Os fatores trabalho e capital 
são empregados em todos os setores, sendo considerados perfeitamente móveis dentro de uma região em particular.

Quanto aos insumos intermediários, admite-se também a separabilidade, ou seja, a combinação de insumos intermediários independe dos preços dos fatores primários. Admite-se, ainda, a separabilidade entre insumos domésticos e importados, o que implica que a firma decide, inicialmente, a fonte de suas importações e, com base nos preços de importação, determina a combinação ótima de insumos domésticos e importados. Essa especificação consiste na formulação Armington, para modelagem da demanda de importação.

O comércio internacional equilibra o mercado de produtos, sendo cada produto diferenciado pela sua origem (a pressuposição de Armington é aplicada ao país).

Direcionando-se a análise para o comportamento dos indivíduos, verificase, conforme mencionado, que o comportamento do consumo regional é governado por uma função de utilidade agregada que depende do consumo privado, das despesas do governo e da poupança. Assim, a renda regional é distribuída de acordo com uma função utilidade per capita Cobb-Douglas, definida por três formas de demanda final - consumo privado, consumo do governo e poupança, conforme a equação (4):

$$
U=K \cdot C P^{\theta C P} \cdot C G^{\theta C G} \cdot S^{\theta S}
$$

em que $U$ é o nível de utilidade total em cada região $K$, e $\theta$ são parâmetros da função. A maximização da função utilidade acima determina a alocação da renda em cada região, entre as três formas de demanda.

Como a função de utilidade é uma Cobb-Douglas, o fechamento padrão do Gtap faz com que a participação de cada um daqueles itens da demanda final na renda total seja constante.

\subsection{Fechamento macroeconômico do modelo e alocação do investi- mento entre regiões}

À semelhança da maioria dos modelos aplicados de equilíbrio geral, o Gtap não considera as políticas macroeconômicas e os fenômenos monetários que, normalmente, são fatores explicativos do investimento agregado. Além disso, por não ser um modelo intertemporal (dinâmico) ou seqüenciado no tempo, o que possibilitaria a obtenção de séries de equilíbrio no tempo, o 
investimento não é capaz, no modelo, de afetar a capacidade produtiva das indústrias/regiões, e alterações na sua alocação entre regiões apenas afetam a produção e o comércio por meio de seus efeitos sobre a demanda final. Essas observações justificam maior atenção a esta questão, além de o tratamento da ligação entre poupança e investimento ser necessário para completar o sistema econômico global, assegurando consistência no sistema de contas.

A ausência de um mecanismo intertemporal para determinação do investimento gera o problema do fechamento macroeconômico, para o qual há quatro soluções comumente aceitas. Dessas soluções, três correspondem a fechamentos neoclássicos, nos quais o investimento é fixado e outra fonte de ajustamento é permitida, enquanto a quarta regra permite que o investimento se ajuste, acomodando, neste caso, apenas as mudanças na poupança, isto é, não se estabelece nenhuma relação de investimento independente.

Além do fechamento com relação ao investimento, torna-se necessário lidar com as mudanças potenciais na conta corrente. Um dos procedimentos mais comumente adotados consiste em forçar a poupança e o investimento domésticos a se moverem numa mesma direção, o que se consegue pela fixação do balanço da conta corrente, isto é, fixando o lado esquerdo da identidade das contas nacionais (5):

$$
S-I \equiv X+R-M
$$

em que $S$ é a poupança; $I$, o investimento; $X$, as exportações; $M$, as importações; e $R$, as transferências internacionais.

Ao se fixar regionalmente o lado direito da identidade (5), a parcela com que cada região desfruta da poupança líquida global está sendo fixada; desse modo, a igualdade entre a poupança e o investimento global no equilíbrio é assegurada, mesmo sem a presença de um banco global para fazer, explicitamente, a intermediação entre a poupança e o investimento global. Este é também um fechamento neoclássico, uma vez que o investimento deve ajustarse, em alinhamento, às mudanças regionais da poupança.

Porém, em certos experimentos, almeja-se que ambos os lados da identidade sejam endógenos, o que requer um mecanismo que assegure a igualdade entre a demanda global de poupança e a demanda global de investimento, que, no caso do Gtap, corresponde ao "banco global". Portanto, o fechamento global também é neoclássico. 
Por fim, como os modelos aplicados de equilíbrio geral são fundamentados no modelo walrasiano de equilíbrio geral, em que os preços são relativos, é necessário escolher um bem como numéraire, em relação ao qual todos os preços do modelo são expressos. No modelo Gtap, o numéraire é o preço da poupança global (psave).

\subsection{Cenários}

Para analisar os efeitos da Alca e da fusão do Mercosul com a União Européia, são simulados dois cenários. No primeiro cenário implementa-se a Alca. A criação de uma área de livre comércio no continente americano, com exceção de Cuba, é simulada pela imposição de uma tarifa zero para o comércio entre os países das Américas. Para mantê-la como uma área de livre comércio, nenhuma tarifa externa comum é imposta. A estrutura do Mercosul é mantida com a sua tarifa externa comum sendo observada para o comércio com países fora do continente americano. Para tornar esta área de livre comércio sustentável, são eliminados todos os subsídios à exportação nos países envolvidos na Alca. Quanto aos subsídios à produção, estes permanecem, uma vez que as alterações recentes nas políticas agrícolas americana e européia tornam estes subsídios inatingíveis pelos acordos da Rodada Uruguai e do Milênio.

O segundo cenário visa examinar os impactos de um possível acordo de comércio entre os países do Mercosul e da União Européia, intitulado Mercoeuro neste trabalho. A possibilidade de tal acordo advém das negociações desencadeadas pela Cimeira do Rio de Janeiro, em 1999. Vale lembrar que esta reunião envolveu todos os países da América Latina; no entanto, optou-se aqui pela análise de um acordo somente entre o Mercosul e União Européia, pelo fato de que o único bloco econômico consolidado na América Latina é o Mercosul. Este cenário será implementado pela eliminação das tarifas à importação entre os países acordantes, União Européia, Argentina, Brasil e Chile.

Ainda, como no cenário anterior, considera-se a eliminação dos subsídios às exportações por parte dos países envolvidos, já que esta deve ser uma exigência para que tal acordo se torne sustentável. Vale lembrar que tais considerações são muito otimistas, em face da tradição européia de proteção à produção agrícola, com elevados subsídios à produção e às exportações. Dessa forma, o cenário aqui simulado procura mostrar os efeitos potenciais advindos da formação de uma área de livre comércio, considerando que esta seja a 
tendência, mas reconhecendo que a eliminação dos subsídios às exportações pode não ser atingida no curto prazo, comprometendo a competitividade dos países do Mercosul em alguns produtos importados. Como no cenário Alca, mantêm-se os subsídios à produção entre os países envolvidos no Mercoeuro. Ainda, são reconhecidas a complexidade e possibilidades de resultados diferenciados para os produtos em questão, bem como a morosidade e cautela nas negociações por parte dos países envolvidos.

As distorções existentes nas economias dos países em estudo, como capturado pelo conjunto de dados do Gtap, são apresentadas, a título de exemplo, na tabela 2. Não há nenhum subsídio à produção agrícola $(T O>1)$ na Argentina, Brasil e Chile. Para comparação, os subsídios à produção agrícola podem ser tão altos quanto $57,3 \%$ para o arroz nos EUA, ou $71 \%$ para outras culturas na União Européia. Tarifas negativas, o mesmo que subsídios para as importações, ${ }^{3}$ não fazem sentido como compromissos tarifários, pois não é esperado que um país negocie ou se comprometa com a OMC com importações subsidiadas. Tarifa negativa é tratada como falha do Gtap e é considerada zero para propósito de simulação.

Tabela 2

Distorção na produção doméstica

\begin{tabular}{lcccccccc}
\hline & \multicolumn{7}{c}{ País } \\
\cline { 2 - 8 } Commodity & Brasil & Argentina & Chile & EUA & Canadá & México & LAM & UE \\
\hline Arroz & 1,000 & 1,008 & 0,967 & 1,573 & 1,000 & 1,013 & 0,994 & 1,072 \\
Trigo & 1,000 & 1,008 & 0,969 & 1,324 & 1,168 & 1,027 & 1,014 & 1,063 \\
Outros grãos & 1,000 & 1,008 & 0,971 & 1,306 & 1,076 & 1,009 & 0,995 & 1,025 \\
Outras culturas & 1,000 & 1,008 & 0,974 & 1,052 & 1,103 & 1,003 & 0,996 & 1,710 \\
Produtos animais & 1,000 & 1,008 & 0,994 & 1,035 & 1,046 & 0,999 & 0,998 & 1,092 \\
Produtos florestais & 1,000 & 0,999 & 0,992 & 1,000 & 0,991 & 0,959 & 0,980 & 0,985 \\
Alimentos & 1,000 & 0,999 & 0,998 & 1,005 & 1,046 & 0,984 & 0,944 & 0,928 \\
Manufaturados & 1,000 & 1,002 & 0,997 & 1,000 & 0,990 & 0,967 & 0,972 & 0,965 \\
\hline
\end{tabular}

Fonte: Base de dados do Gtap.

Em ambos os cenários consideram-se as restrições impostas pelos acordos da Rodada Uruguai no apoio doméstico à produção agrícola, nos subsídios à exportação de produtos agrícolas e nas tarifas à importação, ou seja, aqueles acordos comerciais já firmados junto à OMC. Dessa forma, a Rodada Uruguai estabelece, para a agricultura, uma redução de $20 \%$ no subsídio à produção

\footnotetext{
${ }^{3}$ As distorções nas importações e exportações podem ser consultadas no banco de dados do Gtap.
} 
doméstica para os países desenvolvidos, no prazo de seis anos, com período base 1986-88, com exceção da União Européia, para a qual foi fixada uma redução de 16,8\%; para os países em desenvolvimento é exigida uma redução de 13,3\% no prazo de 10 anos. Quanto aos subsídios às exportações, estes devem ser reduzidos em $36 \%$ no prazo de seis anos nos países desenvolvidos e, nos países em desenvolvimento, em $24 \%$ no prazo de 10 anos. Tarifas à importação, no mesmo período, devem ser reduzidas, na média, em $36 \%$ nos países desenvolvidos e $24 \%$ nos países em desenvolvimento.

Nos dois cenários também consideram-se os acordos estabelecidos pelas negociações do Mercosul, ou seja, tarifa zero às importações para o comércio entre os países-membros. O Mercosul completo é imposto pela eliminação dos subsídios à produção e exportação agrícola para o comércio entre Argentina, Brasil e Chile e uma tarifa externa comum (TEC) é imposta para a importação de todos os países não pertencentes ao Mercosul e demais países que fazem parte dos acordos comerciais nos cenários em estudo. Assim, no cenário Alca, a TEC é imposta apenas entre os países do Mercosul e demais países nãomembros da Alca, enquanto no cenário Mercoeuro, a TEC só não incide sobre os países da União Européia.

\section{Resultados}

Os resultados referentes aos cenários são apresentados em valores percentuais das mudanças ocorridas nos indicadores econômicos de quantidades, preços, termos de comércio, balança comercial (sendo este apresentado em US\$ milhões), PIB (produto interno bruto), variação equivalente ${ }^{4}$ (também expressa em US\$ milhões) e utilidade per capita, para os países envolvidos em cada cenário.

Inicialmente, apresentam-se os valores da produção, exportação e importação das commodities arroz, trigo, outros grãos (milho e outros cereais), outras culturas (soja, café e cana-de-açúcar), produtos animais, produtos florestais, alimentos e manufaturas, para os diversos países envolvidos, antes da implementação dos cenários, para melhor visualização dos impactos advindos das reformas (tabelas 3,4 e 5).

\footnotetext{
${ }^{4}$ Multiplicação do aumento da utilidade per capita pela renda do país, mede o ganho de bem-estar.
} 


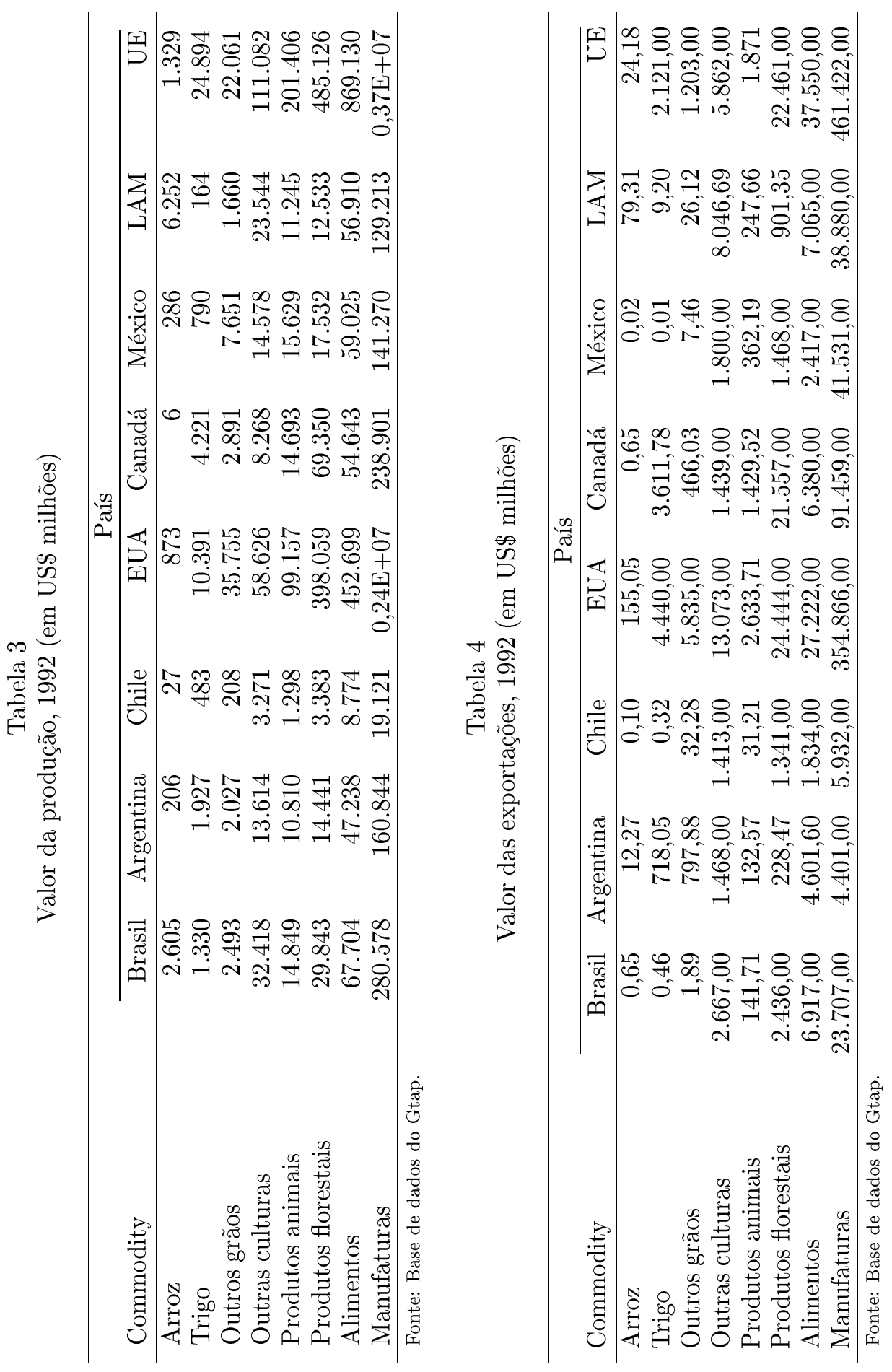




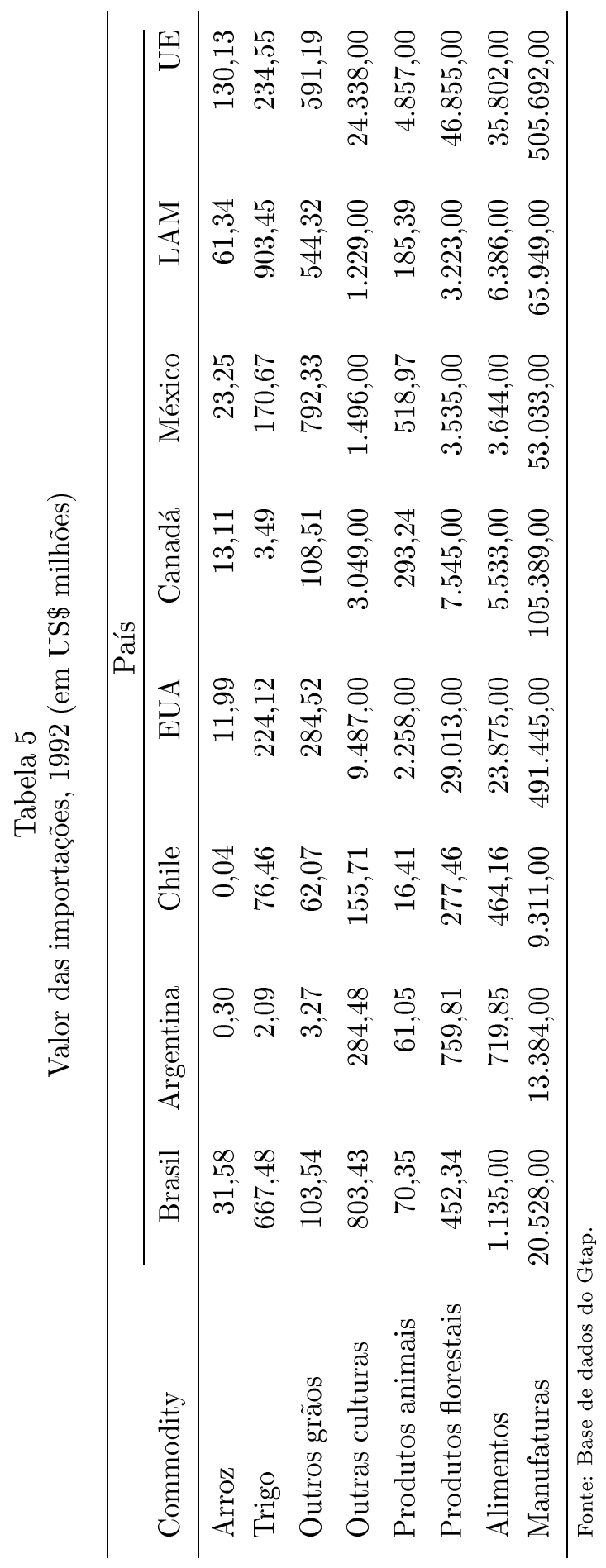


Verifica-se que o valor da produção da commodity arroz é maior na região LAM (que engloba os demais países da América Latina), seguida pelo Brasil. Para o trigo, a União Européia (UE ) se destaca, seguida dos EUA e Canadá. Os EUA e a UE são hegemônicas no valor da produção das demais commodities. Quanto ao valor das exportações (tabela 4), para todas as commodities os EUA e a UE são preponderantes, sendo que, para arroz e outras culturas, a LAM também tem altos valores das exportações, assim como o Canadá para as commodities trigo e produtos florestais.

No que se refere ao valor das importações (tabela 5), para as commodities arroz, trigo e outros grãos a região LAM possui elevados valores, o mesmo sendo verificado para a UE com os produtos arroz e outros grãos, para o Brasil como trigo, e para o México com outros grãos. Para as commodities outras culturas, produtos animais, produtos florestais, alimentos e manufaturas, as regiões EUA e UE possuem os maiores valores nas importações.

\subsection{Cenário Alca}

Neste cenário, os resultados refletem, além daqueles acordos referentes às negociações da Rodada Uruguai e Mercosul, o que ocorreria com a adoção da Área de Livre Comércio das Américas (Alca). Vale ressaltar que, além da eliminação das tarifas à importação, admite-se que os países acordantes eliminem os subsídios às exportações.

A tabela 6 apresenta os resultados para as variações nas quantidades produzidas para os países da Alca. Pode-se verificar que, em geral, ocorre uma pequena variação da produção nos países do Mercosul para quase todas as culturas, com exceção do trigo no Brasil, cuja produção cai 22,5\%, ao mesmo tempo que a produção tritícola Argentina cresce 14,3\%. De acordo com Bitencourt (2000), esta redução deve-se à eliminação das tarifas de importação entre os países do Mercosul, que expõe o Brasil a uma maior competição, principalmente em relação à Argentina, revelando, assim, a posição de baixa capacidade competitiva do Brasil em relação ao trigo importado.

Para os EUA ocorrem consideráveis reduções na produção das commodities trigo e outras culturas, devido à eliminação dos subsídios à exportação, o que mostra, portanto, a forte intervenção americana nesses mercados. Para o Canadá, observam-se aumentos consideráveis para a commodity trigo, o que mostra a competitividade desse país nesta atividade. Para o México e LAM, 
observa-se o mesmo sentido de variação em todas as commodities, sendo que outras culturas são responsáveis pelos maiores aumentos.

Tabela 6

Mudanças percentuais na quantidade produzida $\left(q_{0}\right)$ para os países da Alca

\begin{tabular}{lrrrrrrr}
\hline & \multicolumn{7}{c}{ País } \\
\cline { 2 - 8 } Commodity & Brasil & Argentina & Chile & EUA & Canadá & México & LAM \\
\hline Arroz & 2,14 & 0,12 & 1,07 & $-2,69$ & 8,99 & $-1,17$ & $-1,80$ \\
Trigo & $-22,53$ & 14,35 & 7,71 & $-9,92$ & 5,92 & 0,56 & 54,00 \\
Outros grãos & 3,02 & 5,60 & 3,17 & $-0,56$ & $-5,01$ & $-2,24$ & $-0,26$ \\
Outras culturas & 2,92 & 2,28 & 11,63 & $-5,98$ & $-5,58$ & 14,57 & 7,06 \\
Produtos animais & 1,40 & 2,29 & 1,02 & 0,07 & 0,95 & $-1,60$ & $-1,20$ \\
Produtos florestais & 0,23 & $-1,87$ & $-2,36$ & $-0,01$ & 0,09 & $-1,66$ & $-2,44$ \\
Alimentos & 1,81 & 2,98 & 2,15 & 0,47 & 0,20 & $-1,30$ & $-1,69$ \\
Manufaturas & $-1,61$ & $-1,26$ & $-0,15$ & 0,44 & 0,08 & 0,48 & 1,43 \\
\hline
\end{tabular}

Fonte: Base de dados da pesquisa.

Na tabela 7 é apresentada a variação da quantidade exportada pelos países da Alca. As exportações da Argentina aumentam para todos os produtos, menos para o arroz. Para o Brasil, a Alca aumenta consideravelmente as exportações para outras culturas $(15,44 \%)$, para alimentos $(15,26 \%)$ e para manufaturas $(41,84 \%)$, mostrando a forte competitividade das commodities agrícolas brasileiras. Cabe ressaltar que, apesar do resultado favorável quanto ao trigo, as exportações são inexpressivas. Nos EUA verificam-se reduções na quantidade exportada de arroz, trigo, outros grãos e produtos animais, e aumentos consideráveis para as commodities outras culturas. Para o Canadá, o acordo da Alca é bastante favorável, pois, para todas as culturas, com exceção de outros grãos, ocorrem aumentos.

A tabela 8 apresenta os resultados para as variações nas quantidades importadas para os países da Alca. Para o Brasil, ocorrem reduções consideráveis nas importações de outras culturas (soja, café e cana-de-açúcar), de 33,08\%. A eliminação das tarifas à importação entre os países-membros da Alca faz com que o país se torne mais competitivo naquelas commodities agrícolas em que detém uma maior vantagem comparativa. Ao mesmo tempo, há um aumento nas importações de trigo, alimentos, produtos florestais e manufaturas. Para a Argentina e o Chile, ocorrem aumentos nas importações de outras culturas, produtos florestais, alimentos e manufaturas. Quanto aos EUA e Canadá, verificam-se aumentos consideráveis nas importações das commodities outras 
culturas, o que mostra, portanto, a intervenção governamental atualmente existente nesses mercados.

Tabela 7

Mudanças percentuais na quantidade exportada ( $q x w)$ para os países da Alca

\begin{tabular}{lrrrrrrr}
\hline & \multicolumn{7}{c}{ País } \\
\cline { 2 - 7 } Commodity & Brasil & Argentina & Chile & \multicolumn{1}{c}{ EUA } & Canadá & México & LAM \\
\hline Arroz & 19,75 & $-41,12$ & 13,83 & $-12,14$ & 27,52 & 39,44 & 12,27 \\
Trigo & 62,09 & 30,71 & 32,54 & $-17,12$ & 6,38 & 31,57 & $-8,77$ \\
Outros grãos & $-2,12$ & 9,80 & 12,69 & $-3,89$ & $-19,42$ & $-10,20$ & $-9,82$ \\
Outras culturas & 15,44 & 15,51 & 27,94 & 18,23 & 25,85 & 136,27 & 24,94 \\
Produção animais & $-2,31$ & 12,46 & 3,17 & $-3,76$ & 7,59 & $-9,68$ & 3,47 \\
Produção florestais & 3,30 & 23,74 & 2,46 & 1,07 & 0,30 & 7,49 & 32,98 \\
Alimentos & 15,26 & 32,02 & 17,18 & 9,41 & 11,18 & 11,71 & 12,37 \\
Manufaturas & 41,84 & 110,45 & 24,31 & 6,49 & 1,41 & 20,28 & 27,22 \\
\hline
\end{tabular}

Fonte: Base de dados da pesquisa.

Tabela 8

Mudanças percentuais na quantidade importada (qiw) para os países da Alca

\begin{tabular}{lrrrrrrr}
\hline & \multicolumn{7}{c}{ País } \\
\cline { 2 - 8 } Commodity & Brasil & Argentina & Chile & EUA & Canadá & México & LAM \\
\hline Arroz & $-54,03$ & 11,51 & 64,38 & 15,86 & $-2,27$ & $-2,22$ & 39,97 \\
Trigo & 10,06 & $-64,46$ & $-41,15$ & 15,44 & 7,52 & $-8,74$ & $-8,25$ \\
Outros grãos & $-28,02$ & $-10,39$ & 0,31 & $-8,52$ & 41,32 & 11,76 & $-0,93$ \\
Outras culturas & $-33,08$ & 22,92 & 43,25 & 55,36 & 23,78 & 17,27 & 23,74 \\
Produtos animais & 16,33 & 29,52 & 51,81 & 4,96 & $-0,87$ & 8,62 & 27,13 \\
Produtos florestais & 25,69 & 31,03 & 32,72 & 1,78 & 0,25 & 9,25 & 17,17 \\
Alimentos & 26,77 & 23,05 & 34,53 & 4,34 & 12,08 & 19,95 & 26,61 \\
Manufaturas & 51,33 & 45,46 & 17,43 & 40,2 & 1,32 & 16,11 & 15,88 \\
\hline
\end{tabular}

Fonte: Base de dados da pesquisa.

A tabela 9 apresenta os resultados das mudanças na balança comercial. De um modo geral, verifica-se que a Alca é favorável, em termos de balança comercial, para o Brasil, Argentina, Chile e México. Vale ressaltar que isto é conseqüência de aumento no valor das exportações superior ao das importações, ou queda maior no valor das importações do que no das exportações. Para os EUA, Canadá e LAM são apresentados déficits, mostrando que a maior liberalização comercial proporciona vantagens comerciais para os países em desenvolvimento. Cabe ressaltar que o item serviços foi incluído somente para fechar o total. 


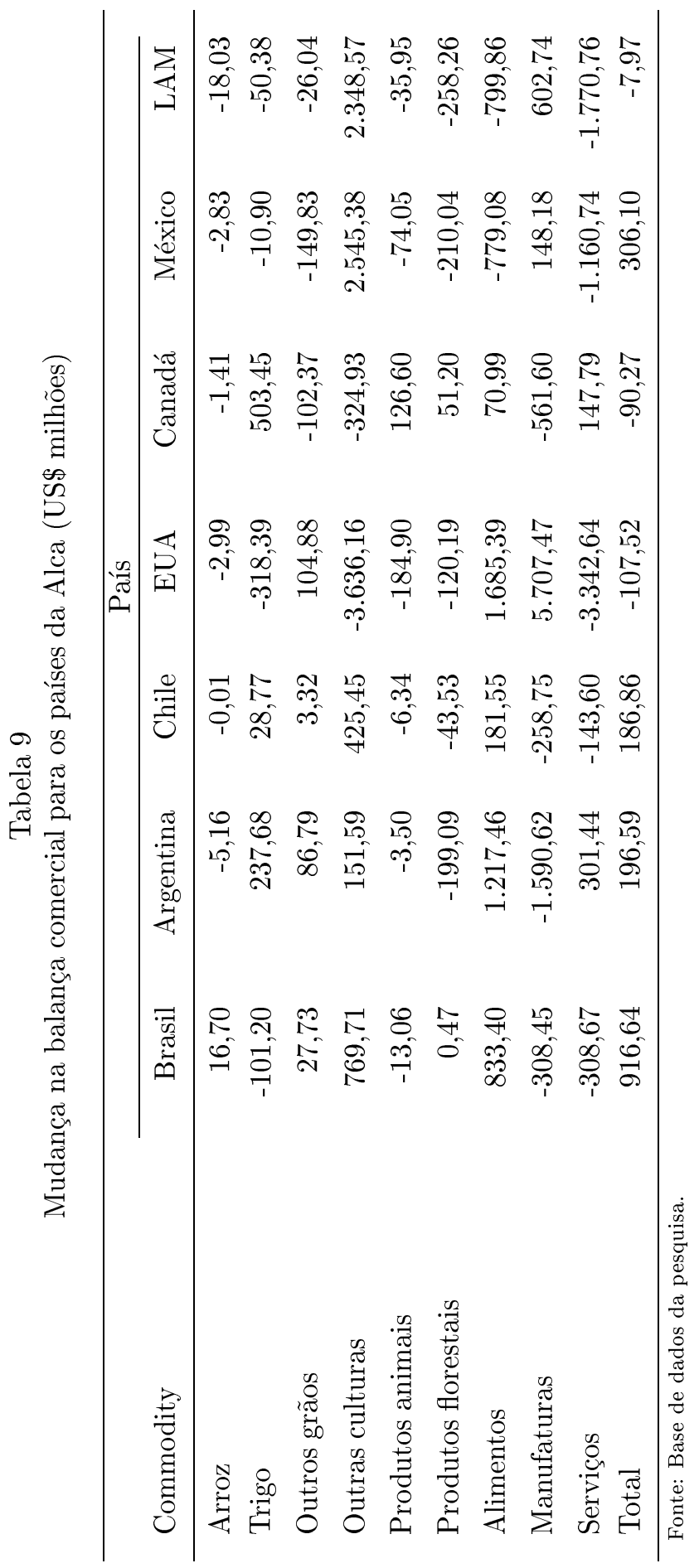


As variações em quantidades produzidas e comercializadas e na balança comercial revelam que os impactos da formação da Alca são mais intensos sobre os fluxos de comércio internacional, enquanto as variações na produção doméstica dos países-membros são pequenas.

Uma questão importante na análise dos benefícios da formação dos blocos regionais é a da criação ou do desvio de comércio. Caso a formação do bloco gere mais criação do que desvio de comércio, tem-se, então, aumento no bemestar da população. O modelo Gtap permite, por meio das variáveis volume das exportações agregadas (qxwreg) e volume das importações agregadas ( $q$ iwreg), determinar se houve criação ou desvio de comércio em nível agregado. Dessa forma, caso o volume de comércio (importação e exportação) aumente em todos os países do bloco, tem-se criação de comércio.

De acordo com a base de dados do Gtap, o volume exportado do Brasil, Argentina, Chile, EUA e Canadá aumentou 28,49\%, 49,08\%, 15,16\%, 3,84\% e $1,92 \%$, respectivamente. Quanto ao volume importado agregado, houve aumento de 36,07\%, para o Brasil; 32,15\%, para a Argentina; 15,94\% para o Chile; 4,45\%, para os EUA; e 1,87\% para o Canadá. Portanto, ocorreu aumento no volume comercializado de todos os países analisados pertencentes à Alca, o que implica criação de comércio.

Analisando as mudanças percentuais no preço de exportação para os países da Alca, verifica-se que, de acordo com a tabela 10, para os países do Mercosul as variações em preços são pequenas, sendo que para o Brasil o aumento mais relevante é para outros grãos, em 4,7\%. Com relação aos EUA, nota-se que a queda nos subsídios à exportação, concomitantemente com a queda na produção doméstica e nas exportações de algumas culturas, resulta em um aumento significativo nos preços de exportação. Para o Canadá o efeito da maior liberalização do comércio é um aumento em seus preços de exportação. Para a região LAM e México observa-se a elevação de todos os preços, cabendo ressaltar que estes países são tomadores de preços, portanto, o efeito da redução nos subsídios à exportação nos países desenvolvidos causa reflexos nestes países.

Os preços globais de importação aumentam para todos os produtos, porém em pequena magnitude (tabela 11). Dessa forma, percebe-se que a eliminação de tarifas às importações entre os países envolvidos tem um efeito de aumento nos preços internacionais de importação, o que pode ser explicado pelo aumento na demanda de importação dos países. 
Tabela 10

Mudanças percentuais no preço de exportação (Pxw) para os países da Alca

\begin{tabular}{lrcrrrrr}
\hline & \multicolumn{7}{c}{ País } \\
\cline { 2 - 7 } Commodity & Brasil & Argentina & Chile & EUA & Canadá & México & LAM \\
\hline Arroz & 2,69 & $-0,87$ & 5,71 & 13,20 & 1,15 & 5,76 & 5,84 \\
Trigo & 0,93 & 1,71 & 5,76 & 13,68 & 7,13 & 6,26 & 13,17 \\
Outros grãos & 4,70 & 0,96 & 4,21 & 5,95 & 11,27 & 5,78 & 6,07 \\
Outras culturas & 3,91 & 0,24 & 5,92 & 0,69 & 4,74 & 8,94 & 6,89 \\
Produtos animais & 2,64 & 0,54 & 5,46 & 2,87 & 1,48 & 6,01 & 5,35 \\
Produtos florestais & 1,50 & $-2,90$ & 1,14 & 0,93 & 0,29 & 2,36 & 2,37 \\
Alimentos & 1,53 & $-1,01$ & 2,15 & 2,22 & 2,14 & 3,46 & 4,59 \\
Manufaturas & $-0,28$ & $-3,69$ & $-0,99$ & 0,84 & 0,14 & 1,29 & 1,60 \\
\hline
\end{tabular}

Fonte: Base de dados da pesquisa.

Tabela 11

Mudanças percentuais no preço de importação (Piw) para os países da Alca

\begin{tabular}{lccrrrrr}
\hline & \multicolumn{7}{c}{ País } \\
\cline { 2 - 8 } Commodity & Brasil & Argentina & Chile & EUA & Canadá & México & LAM \\
\hline Arroz & 3,51 & 5,57 & 0,84 & 1,84 & 14,77 & 14,77 & 9,88 \\
Trigo & 4,68 & 24,66 & 6,28 & 10,46 & 24,84 & 16,58 & 15,11 \\
Outros grãos & 1,78 & 6,13 & 3,40 & 10,05 & 6,07 & 6,35 & 5,56 \\
Outras culturas & 2,81 & 4,30 & 4,04 & 5,93 & 1,53 & 1,73 & 3,92 \\
Produtos animais & 2,47 & 3,55 & 2,33 & 1,97 & 2,46 & 2,47 & 3,37 \\
Produtos florestais & 0,47 & 0,93 & 0,39 & 0,32 & 0,73 & 0,79 & 0,81 \\
Alimentos & 2,67 & 3,24 & 3,01 & 2,01 & 2,03 & 5,92 & 4,19 \\
Manufaturas & 0,12 & 0,14 & 0,08 & 0,14 & 0,55 & 0,61 & 0,39 \\
\hline
\end{tabular}

Fonte: Base de dados da pesquisa.

Na tabela 12, são analisados os termos de troca (Tot) que correspondem à diferença entre o índice de preço recebido para exportação ( $p s w)$ e o índice de preço pago por importação $(P d w)$. Vale ressaltar que termos de troca, por definição, é a razão entre os preços internacionais e os preços domésticos; no entanto, o Gtap traz índices de preços, isto é, já está inclusa a razão entre os preços. As mudanças ocorridas nos termos de comércio nos países da Alca revelam ser favoráveis para os EUA, México e LAM, devido ao fato de os preços pagos pelas importações serem menores que os preços recebidos pelas exportações. Neste caso, esta diferença é igual à variação no preço doméstico. Essas variações positivas podem ser explicadas pela presença de subsídios às exportações nos preços recebidos pela exportação da maioria dos produtos, 
o que eleva esses preços consideravelmente, em detrimento dos preços de importação. Para a Argentina e o Chile essas variações são desfavoráveis. Os demais países obtiveram variação pequena, não sendo, portanto, considerados. Assim, a formação da Alca não parece trazer vantagens nos termos de comércio para os países do Mercosul.

Na tabela 13 são analisados o indicador de crescimento econômico - o produto interno bruto (PIB) - e os indicadores de bem-estar - utilidade per capita $(U)$ e variação equilvanete $(V E)$. De acordo com Varian (1993), a utilidade indica o nível de satisfação de cada bem ou serviço consumido durante certo período de tempo. No modelo Gtap, a utilidade é representada pelo consumo privado e do governo e pela poupança; portanto, as variações na utilidade estão explicitadas de forma agregada e per capita. A variação equivalente é uma medida de bem-estar que mede, em termos monetários, o impacto de uma variação de preço na utilidade do consumidor, ou seja, consiste em perguntar quanto dinheiro teria de se dar ao consumidor antes da redução de preço, para lhe deixar tão bem quanto estaria depois da variação de preço.

Tabela 12

Mudanças percentuais nos termos de comércio (Tot) nos países da Alca

\begin{tabular}{lccccccc}
\hline & \multicolumn{7}{c}{ País } \\
\cline { 2 - 8 } Variável & Brasil & Argentina & Chile & EUA & Canadá & México & LAM \\
\hline Tot & 0,02 & $-2,69$ & $-0,28$ & 0,75 & $-0,06$ & 0,79 & 1,35 \\
\hline
\end{tabular}

Fonte: Base de dados da pesquisa.

Tabela 13

Mudanças percentuais no produto interno bruto (PIB) e utilidade per capita e variação equivalente (US\$ milhões) nos países da Alca

\begin{tabular}{lrrrrrrr}
\hline & \multicolumn{7}{c}{ País } \\
\cline { 2 - 8 } Variável & Brasil & Argentina & Chile & EUA & Canadá & México & \multicolumn{1}{c}{ LAM } \\
\hline PIB & 2,00 & $-2,41$ & 0,22 & 0,97 & 0,14 & 2,57 & 2,41 \\
$U$ & 1,29 & 0,05 & $-0,13$ & 0,16 & 0,01 & 0,29 & 0,67 \\
$E V$ & $4.572,95$ & 101,89 & $-47,52$ & $8.704,79$ & 57,591 & 840,59 & $1.395,81$ \\
\hline
\end{tabular}

Fonte: Base de dados da pesquisa.

De acordo com os resultados da tabela 13, a formação da Alca traz pequeno aumento do PIB para o Brasil e o Chile; no entanto, para a Argentina, observase redução. Cabe ressaltar que, pelo fato de o modelo Gtap ser baseado em pressuposições neoclássicas de pleno emprego, um acordo de liberalização 
comercial não tem impactos significativos no crescimento econômico, independentemente do produto que se está analisando. No Gtap, o PIB é constituído pelos gastos dos agentes privados (famílias), pelos gastos do governo, pelo valor da produção e pela diferença entre o valor das exportações e o valor das importações. Esses resultados sugerem uma alocação de recursos em favor do crescimento econômico no Brasil e no Chile sob o acordo da Alca. As regiões com maior crescimento econômico são México e LAM. Para o Canadá e os EUA a liberalização comercial traz aumentos modestos no PIB.

Ao se analisar a utilidade per capita e variação equivalente, estas são positivas para todos os países, exceto Chile, sendo mais significativas para o Brasil e pouco expressivas para Argentina e Canadá. Maior crescimento econômico promove melhoria no nível de renda e gera, como conseqüência, aumento no consumo. Com um preço de mercado (exportação) um pouco maior, a satisfação também aumenta. Os efeitos positivos na utilidade per capita, para o Brasil, causaram crescimento ainda maior na variação equivalente. Portanto, o acordo da Alca promove ganhos de bem-estar, ainda que pequenos, para a maioria dos países, com exceção do México.

Verifica-se, de um modo geral, que a formação da Alca não traz grandes variações em termos de produção e bem-estar; porém, dinamiza os fluxos de comércio entre os países do acordo. Para o Brasil em particular nota-se que, entre as commodities agrícolas, o trigo é afetado negativamente, enquanto os produtos exportáveis (outras culturas) têm ganhos de comércio. O Brasil se torna mais dinâmico no comércio internacional de produtos manufaturados, uma vez que elevam-se as variações exportadas e importadas desse setor.

\subsection{Cenário Mercoeuro}

No segundo cenário os resultados referem-se às variações nos indicadores econômicos resultantes da criação de uma área de livre comércio entre os países do Mercosul e aqueles países da União Européia. Vale ressaltar que, além da redução das tarifas de importação, admite-se que os países acordantes eliminem os subsídios às exportações. Quanto aos subsídios à produção, estes são reduzidos apenas segundo as exigências da Rodada Uruguai.

A tabela 14 apresenta os resultados para as variações nas quantidades produzidas para os países do Mercoeuro. 
Tabela 14

Mudanças percentuais na quantidade produzida (qo) para os países do Mercoeuro

\begin{tabular}{lrcrr}
\hline & \multicolumn{4}{c}{ País } \\
\cline { 2 - 5 } Commodity & Brasil & Argentina & Chile & \multicolumn{1}{c}{ UE } \\
\hline Arroz & 4,53 & 3,23 & $-0,22$ & $-6,73$ \\
Trigo & $-16,27$ & 9,36 & 6,36 & $-15,12$ \\
Outros grãos & 8,28 & 15,40 & 17,37 & $-13,89$ \\
Outras culturas & 15,07 & 15,69 & 29,95 & $-9,70$ \\
Produtos animais & 3,78 & 2,37 & $-1,37$ & $-1,36$ \\
Produtos florestais & $-0,42$ & $-2,62$ & $-4,35$ & 0,28 \\
Alimentos & 4,33 & 3,79 & 0,03 & $-1,67$ \\
Manufaturas & $-4,66$ & $-3,68$ & $-4,32$ & 0,72 \\
\hline
\end{tabular}

Fonte: Base de dados da pesquisa.

Verifica-se que a criação de uma área de livre comércio entre os países do Mercosul e a UE provocaria aumentos mais relevantes na produção brasileira de outros grãos e outras culturas, enquanto a produção de trigo sofreria uma redução menor em comparação com o cenário Alca. Para a Argentina e o Chile ocorrem aumentos na produção de outros grãos, outras culturas e trigo. Para a UE, pode-se notar que o acordo com o Mercosul traria redução em praticamente todas as commodities consideradas, com expressiva diminuição da produção de trigo, outros grãos e outras culturas.

Comparando os resultados do primeiro com os do segundo cenário, percebe-se que ocorre, em geral, um aumento maior nas quantidades produzidas das commodities para os países do Mercosul quando da criação da área de livre comércio com a União Européia. Exceção são os produtos manufaturados, que têm sua produção reduzida mais fortemente no segundo cenário.

Pela tabela 15 pode-se visualizar os efeitos deste segundo cenário sobre o volume de exportações dos países envolvidos.

Pode-se verificar que as exportações da commodity outras culturas crescem significativamente nos países do Mercosul, sendo o produto de maior crescimento nestes países. As exportações brasileiras também crescem para alimentos e manufaturas. As variações observadas para o arroz, trigo e outros grãos não são importantes, devido aos inexpressivos valores exportados dessas commodities pelo país, apresentados na tabela 4. Para a Argentina, é possível notar que as exportações expandem também para manufaturas e, em menor proporção, para alimentos, outros grãos e trigo. A UE sofre forte redução nas exportações de arroz, outros grãos, trigo, outras culturas e alimentos. Ape- 
nas manufaturas e produtos animais sofrem aumento das exportações nesta região.

Tabela 15

Mudanças percentuais na quantidade exportada ( $q x w)$ pelos países do Mercoeuro

\begin{tabular}{lrcrr}
\hline & \multicolumn{4}{c}{ País } \\
\cline { 2 - 5 } Commodity & Brasil & Argentina & Chile & \multicolumn{1}{c}{ UE } \\
\hline Arroz & 6,91 & $-4,08$ & 38,93 & $-78,04$ \\
Trigo & 20,71 & 17,51 & $-5,15$ & $-54,99$ \\
Outros grãos & 108,09 & 32,69 & 95,91 & $-63,24$ \\
Outras culturas & 149,18 & 138,27 & 68,00 & $-36,66$ \\
Produtos animais & $-13,88$ & $-11,48$ & $-14,55$ & $-0,31$ \\
Produtos florestais & $-0,53$ & 2,75 & $-1,58$ & 1,32 \\
Alimentos & 32,74 & 40,41 & 6,86 & $-19,72$ \\
Manufaturas & 19,48 & 64,68 & 9,92 & 3,67 \\
\hline
\end{tabular}

Fonte: Base de dados da pesquisa.

Quando se comparam os dois cenários simulados, verifica-se que as quantidades exportadas sofrem maior aumento no segundo cenário para as commodities outros grãos, outras culturas e alimentos, para os países do Mercosul. As exportações dos produtos animais e florestais crescem com a Alca e decrescem com a área de livre comércio do Mercosul com a UE. As exportações sofrem um maior aumento com a criação da Alca para manufaturas.

A tabela 16 apresenta os efeitos de uma área de livre comércio entre o Mercosul e a UE sobre o volume de importações dos países envolvidos.

Tabela 16

Mudanças percentuais na quantidade importada (qiw) pelos países do Mercoeuro

\begin{tabular}{lrcrr}
\hline & \multicolumn{4}{c}{ País } \\
\cline { 2 - 5 } Commodity & Brasil & Argentina & Chile & \multicolumn{1}{c}{ UE } \\
\hline Arroz & $-56,41$ & 13,93 & 61,83 & $-3,38$ \\
Trigo & 12,88 & $-60,12$ & $-43,73$ & $-14,56$ \\
Outros grãos & $-30,47$ & $-5,61$ & $-3,12$ & 47,59 \\
Outras culturas & $-33,02$ & 38,19 & 55,52 & 25,91 \\
Produtos animais & 29,51 & 53,67 & 63,42 & 0,72 \\
Produtos florestais & 23,79 & 36,20 & 32,13 & $-0,49$ \\
Alimentos & 13,20 & 22,78 & 23,03 & 5,99 \\
Manufaturas & 50,29 & 51,64 & 14,47 & 0,03 \\
\hline
\end{tabular}

Fonte: Base de dados da pesquisa. 
É possível verificar pela tabela 16 que as importações brasileiras de arroz, outros grãos e outras culturas reduzem-se consideravelmente, enquanto crescem as importações de manufaturas, produtos florestais, alimentos e trigo. Para a Argentina, as reduções nas importações de trigo e outros grãos e o aumento nas importações de arroz não são relevantes, por serem produtos com reduzidos valores de importação por este país. Ocorrem aumentos na quantidade importada dos demais produtos, destacando-se as commodities manufaturas e produtos animais. Para o Chile, aumentos da quantidade importada são consideráveis para outras culturas, alimentos e manufaturas. Arroz não é um produto com expressivo valor das importações chilenas. A UE reduz suas importações de trigo, enquanto ocorrem aumentos consideráveis nas importações de outros grãos e outras culturas.

Percebe-se que um acordo comercial entre Mercosul e UE apresenta vantagens para ambos os lados em termos de volumes de produção e comércio. Os países tendem a incrementar sua produção naqueles produtos em que possuem maior vantagem comparativa, bem como reduzir a produção naqueles de menor vantagem, como é o caso da produção de trigo que cai no Brasil e aumenta na Argentina, o que vai de acordo com as teorias de comércio internacional. Importante exemplo disso são os aumentos na produção e nas exportações dos produtos outros grãos e outras culturas no Mercosul e o aumento das importações destes produtos pela UE. Outro forte exemplo é a redução na produção e o aumento nas importações de manufaturas pelos países do Mercosul. De um modo geral, as exportações dos países do Mercosul são favorecidas, reflexo da redução das barreiras comerciais entre estes e a UE, enquanto as exportações da UE são reduzidas para quase todos os produtos, refletindo a eliminação dos subsídios à exportação naqueles países. Cabe ressaltar que não foram simulados impactos nos subsídios à produção nos países envolvidos e, mesmo assim, as reduções na produção doméstica da UE foram generalizadas, advindas da maior liberação comercial entre este bloco e o Mercosul. Torna-se importante notar também que as vantagens estão presentes para os dois blocos, quando se analisam o aumento considerável das importações por parte dos países do Mercosul e o aumento pouco expressivo nas importações para a maioria das commodities da UE.

É possível afirmar que as variações nas quantidades produzidas e exportadas de commodities agrícolas são mais favoráveis aos países do Mercosul para um acordo destes com a UE, em detrimento da Alca, sendo verificado 
o oposto para produtos manufaturados. Porém, as importações de produtos manufaturados sofrem menores aumentos para Brasil e Chile quando da criação de uma área de livre comércio do Mercoeuro.

A tabela 17 mostra as variações na balança comercial dos países do Mercoeuro decorrentes de uma área de livre comércio entre estes blocos. As variações na balança comercial confirmam os resultados discutidos anteriormente. Dessa forma, nota-se que, para os produtos outros grãos, outras culturas e alimentos, os países do Mercosul apresentam um aumento na balança comercial, enquanto a UE obtém uma redução desta. De forma inversa, ocorre forte redução na balança comercial de manufaturas para os países do Mercosul e aumento expressivo desta para a UE. Verifica-se que o total da balança comercial brasileira tem um aumento expressivo, enquanto na Argentina e no Chile este aumento é menor. A UE sofre uma redução na balança comercial, evidenciando que a variação no valor das importações é maior que no valor das exportações neste bloco.

Tabela 17

Variações na balança comercial dos países do Mercoeuro, em US\$ milhões

\begin{tabular}{lrrrr}
\hline & \multicolumn{4}{c}{ País } \\
\cline { 2 - 5 } Commodity & \multicolumn{1}{c}{ Brasil } & Argentina & \multicolumn{1}{c}{ Chile } & \multicolumn{1}{c}{ UE } \\
\hline Arroz & 17,50 & 0,12 & 0,02 & $-15,70$ \\
Trigo & $-137,91$ & 191,83 & 30,48 & $-846,52$ \\
Outros grãos & 27,67 & 366,50 & 35,59 & $-955,98$ \\
Outras culturas & $4.678,32$ & $2.240,38$ & $1.195,25$ & $-8.812,42$ \\
Produtos animais & $-37,41$ & $-41,33$ & $-12,64$ & $-64,86$ \\
Produtos florestais & $-50,21$ & $-277,02$ & $-88,23$ & 354,49 \\
Alimentos & $2.395,84$ & $1.903,92$ & 79,65 & $-8.061,01$ \\
Manufaturas & $-5.210,32$ & $-4.157,43$ & $-763,44$ & $15.752,58$ \\
Serviços & $-506,08$ & $-212,60$ & $-223,26$ & $3.129,84$ \\
Total & $1.177,40$ & 14,37 & 253,43 & $-151,95$ \\
\hline
\end{tabular}

Fonte: Base de dados da pesquisa.

Quando se comparam as variações na balança comercial dos dois cenários, percebe-se que elas são maiores para o Brasil e o Chile e menores para a Argentina, para o total da balança comercial. Os produtos animais e florestais, bem como as manufaturas, possuem uma variação mais desfavorável no segundo cenário, nos países do Mercosul. As commodities outras culturas e outros grãos têm uma variação mais favorável nos países do Mercosul no segundo cenário. O mesmo ocorre para a commodity alimentos, com exceção do Chile. 
Analisando a questão de criação ou desvio de comércio, o volume exportado agregado do Brasil, Argentina, Chile e UE aumentou 26,17\%, 49,09\%. $11,19 \%$ e $0,98 \%$, respectivamente. Quanto ao volume importado agregado, houve aumento de 35,25\% para o Brasil; 38,50\% para a Argentina; $13,64 \%$ para o Chile; e 0,97\% para a UE. Portanto, tem-se também neste cenário a criação de comércio em todos os países do bloco.

As tabelas 18 e 19 apresentam as variações nos preços internacionais de exportação e importação nos países do Mercosul e na UE.

Tabela 18

Mudanças percentuais no preço da exportação ( $p x w)$ nos países do Mercoeuro

\begin{tabular}{lccrr}
\hline & \multicolumn{4}{c}{ País } \\
\cline { 2 - 5 } Commodity & Brasil & Argentina & Chile & UE \\
\hline Arroz & 5,73 & 5,72 & 10,56 & 37,74 \\
Trigo & 4,17 & 7,70 & 10,58 & 31,42 \\
Outros grãos & 8,54 & 9,99 & 10,93 & 32,88 \\
Outras culturas & 8,63 & 9,66 & 13,83 & 15,99 \\
Produtos animais & 5,67 & 7,81 & 10,63 & 1,46 \\
Produtos florestais & 2,92 & 0,39 & 1,82 & $-0,13$ \\
Alimentos & 4,00 & 4,19 & 4,71 & 7,00 \\
Manufaturas & 0,99 & $-0,55$ & 0,10 & $-0,15$ \\
\hline
\end{tabular}

Fonte: Base de dados da pesquisa.

Tabela 19

Mudanças percentuais no preço da importação ( $p i w)$ nos países do Mercoeuro

\begin{tabular}{lcccc}
\hline & \multicolumn{4}{c}{ País } \\
\cline { 2 - 5 } Commodity & Brasil & Argentina & Chile & UE \\
\hline Arroz & 2,88 & 3,39 & 5,04 & 2,54 \\
Trigo & 6,91 & 11,18 & 6,91 & 6,94 \\
Outros grãos & 8,57 & 7,36 & 7,00 & 6,74 \\
Outras culturas & 4,82 & 4,89 & 3,08 & 3,10 \\
Produtos animais & 1,83 & 2,66 & 1,94 & 1,05 \\
Produtos florestais & 0,18 & 0,88 & 0,52 & 0,31 \\
Alimentos & 6,36 & 7,02 & 5,41 & 1,62 \\
Manufaturas & 0,01 & 0,26 & 0,12 & 0,06 \\
\hline
\end{tabular}

Fonte: Base de dados da pesquisa.

Os preços de exportação aumentam para todos os produtos no Brasil, Chile e Argentina, com exceção de manufaturas na Argentina. Destacamse os aumentos nos preços de exportações para as commodities arroz, trigo, outros grãos e outras culturas na UE. Os aumentos de preços de exportações 
podem ser advindos do aumento na demanda por produtos exportados entre os países a partir da maior liberalização do comércio, bem como das reduções nos subsídios às exportações da UE.

Comparando o primeiro cenário com o segundo, verifica-se que os preços das exportações para os países do Mercosul apresentam maior aumento no segundo cenário para todas as commodities em todos os países.

Os preços de importação aumentam para todas as commodities em todos os países. Maiores aumentos são observados nos preços de importação de trigo e outros grãos em todos os países envolvidos, e alimentos nos países do Mercosul. Menores aumentos nos preços de importação são observados para commodity manufaturas, o que revela que as variações na balança comercial, já discutidas, devem advir quase exclusivamente das variações nas quantidades comercializadas. Dessa forma, percebe-se que a eliminação de tarifas às importações entre os países envolvidos tem um efeito de aumento nos preços internacionais de importação, o que pode ser explicado pelo aumento na demanda de importação dos países.

Pela tabela 20 é possível verificar as variações nos termos de comércio nos países envolvidos neste cenário. A importância deste indicador está em revelar a valorização nos preços dos produtos exportados pelo país em relação à valorização nos preços dos produtos importados, advinda da liberalização comercial.

Tabela 20

Mudanças percentuais nos termos de comércio (Tot) nos países do Mercoeuro

\begin{tabular}{lrccc}
\hline \multirow{2}{*}{ Variável } & Arasil & Argentina & Chile & UE \\
\cline { 2 - 5 } Tot & 1,67 & 1,94 & 1,66 & $-0,03$ \\
\hline
\end{tabular}

Fonte: Base de dados da pesquisa.

As mudanças nos termos de comércio revelam que os países do Mercosul tiveram mudanças nos preços recebidos mais favoráveis que as mudanças nos preços pagos, ou seja, as mudanças nos termos de comércio foram favoráveis para estes países com a liberalização comercial com a UE. Ocorre uma redução inexpressiva nos termos de comércio da UE. Dessa forma, é possível afirmar que os países do Mercosul são favorecidos pelos termos de comércio, enquanto não ocorrem variações significativas nos termos de comércio da UE. 
Comparando os resultados para as variações nos termos de comércio nos dois cenários simulados, nota-se a superioridade do segundo cenário para os países do Mercosul, já que, no primeiro cenário, tais variações foram inexpressivas para o Brasil e desfavoráveis para Argentina e Chile.

A tabela 21 mostra as mudanças ocorridas no PIB, na utilidade per capita e na variação equivalente para os países envolvidos no cenário 2 .

Tabela 21

Mudanças percentuais no produto interno bruto (PIB) e utilidade per capita e variação equivalente (US\$ milhões) nos países do Mercoeuro

\begin{tabular}{lrrrr}
\hline & \multicolumn{4}{c}{ País } \\
\cline { 2 - 5 } Variável & Brasil & Argentina & Chile & \multicolumn{1}{c}{ UE } \\
\hline PIB & 3,56 & 1,82 & 2,37 & 0,12 \\
$U$ & 1,50 & 0,66 & 0,89 & 0,22 \\
$E V$ & $5.307,53$ & $1.278,81$ & 336,48 & $13.858,78$ \\
\hline
\end{tabular}

Fonte: Base de dados da pesquisa.

Percebe-se que a liberalização comercial entre Mercosul e UE traz aumentos modestos no PIB e na utilidade per capita, sendo maiores as variações destes indicadores para o Brasil, seguido do Chile e Argentina, sendo reduzidas as variações para a UE. Quanto à variação equivalente, esta é bem superior para a UE, devido ao valor absoluto da renda ser muito superior nesse bloco econômico que nos demais países, considerando a posição de países desenvolvidos formadores deste bloco. A tendência da variação equivalente é a mesma para os países dentro do Mercosul, ou seja, esta é maior para os países de maior renda absoluta.

Comparando os resultados do segundo cenário com aqueles observados no primeiro, percebe-se que, para os todos os indicadores de bem-estar, as variações são maiores para os países do Mercosul quando da formação de uma área de livre comércio com a UE do que quando da formação da Alca, não ocorrendo valores negativos para nenhum indicador no segundo cenário, diferentemente do primeiro. Dessa forma, o aumento do PIB e do bem-estar é maior para um acordo comercial com a UE.

\section{Conclusão}

A tendência de maior liberalização comercial entre países e blocos econômicos enfrenta críticas e divergências de opiniões entre os economistas. Porém, poucos são os estudos que mensuram os ganhos e perdas de tais acordos. 
Os efeitos sobre a produção advindos da formação da Alca são poucos expressivos para os países do Mercosul, com exceção do trigo para o Brasil, cuja produção apresenta forte redução. Os EUA apresentam, em geral, redução na produção de commodities agrícolas. O Canadá reduz a produção de outros grãos, que incluem basicamente o milho, e outras culturas, que envolvem soja, açúcar, frutas e vegetais. O México e os demais países da América Latina (LAM) incrementam apenas suas produções de outras culturas. A possível formação do Mercoeuro mostra-se mais favorável aos países do Mercosul do que a Alca quanto à produção, com exceção de manufaturas. No entanto, a UE reduz sua produção da maioria das commodities.

As quantidades comercializadas internacionalmente são grandemente afetadas pela formação da Alca e do Mercoeuro, devido à redução nos subsídios à exportação e tarifas à de importação. Verifica-se que, para ambos os cenários, as exportações e importações aumentam para todos os produtos com a liberalização comercial, com poucas exceções. Pela análise da variação da balança comercial, verifica-se que a formação da Alca traz superávits para os países do Mercosul e México, déficits para os EUA, Canadá e LAM. O Mercoeuro provoca maiores ganhos na balança comercial para o Brasil e Chile em relação à Alca. A UE sofre reduções na balança comercial.

Uma questão importante na análise dos benefícios da formação dos blocos regionais é a questão da criação ou desvio de comércio. Dessa forma, verifica-se que a formação de blocos econômicos (Alca e Mercoeuro) gera, em nível agregado, criação de comércio, pois se verificam aumentos nos volumes importados e exportados agregados de todos os países-membros.

A formação dos acordos comerciais em estudo leva, em geral, a maiores variações nos preços globais de exportações e importações para os países desenvolvidos. Os termos de comércio para os países do Mercosul não são favoráveis quando da formação da Alca. Contudo, o cenário Mercoeuro revela-se positivo para os termos de comércio destes países.

A análise do crescimento econômico e ganhos de bem-estar é fundamental para orientar as decisões a respeito da integração comercial entre países e blocos econômicos. Tais indicadores revelam que a Alca traz modestos ganhos para os países envolvidos, sendo que, para Argentina e Chile, alguns indicadores são desfavoráveis. Já o estreitamento das relações de comércio propiciado pelo Mercoeuro traz vantagens de crescimento econômico e bem-estar para todos os países envolvidos. Apesar de tais variações serem de pequena magnitude, são mais expressivas que com a formação da Alca. 
É importante verificar que a liberalização comercial traz incrementos na produção e comercialização dos produtos de maiores vantagens comparativas nos países em questão, como é o caso, em geral, dos produtos agrícolas para os países em desenvolvimento e produtos manufaturados para os países desenvolvidos. Dessa forma, a redução dos subsídios à produção e tarifas de importação trazem ganhos de bem-estar para os países em desenvolvimento e aumentos nos fluxos de comércio para todos os países envolvidos.

Diante desses resultados, pode-se verificar vantagens e desvantagens nos acordos econômicos em estudo. Para os países do Mercosul em geral, e Brasil em particular, nota-se que maiores ganhos devem advir de um acordo com a União Européia. Porém, pelos efeitos diferenciados nas diversas cadeias produtivas, recomenda-se o tratamento diferenciado entre produtos, tanto em termos de liberalização comercial quanto em políticas domésticas, que devem visar ao incremento da produtividade e potencial competitivo dos produtos nacionais sem deixar de lado o ganho de bem-estar e crescimento econômico do país.

\section{Referências Bibliográficas}

Abreu, M. P. O Nafta e as relações econômicas Brasil-Estados Unidos. In: Mercosul e Nafta. O Brasil e a integração hemisférica. Rio de Janeiro, José Olympio, 1995. p. 234-66.

Bitencourt, M. B. Impactos dos acordos da rodada Uruguai, Mercosul, Alca e rodada do milênio na triticultura brasileira - aplicação do modelo Gtap. Viçosa, UFV, 2000. (Tese de Mestrado.)

Carvalho, A. \& Parente, A. Impactos comerciais da área de livre comércio das américas. Brasília, IPEA, 1999. (Texto para Discussão, 635.)

Codsi, G. \& Pearson, K. R. Gempack: general-purpose software for applied general equilibrium and other economic modellers. Computer Science in Economics and Management, 1:189-207, 1988.

Gehlhar, M. et alii. Overview of the Gtap data base. In: Hertel, T. W. (ed.). Global trade analysis: modeling and aplications. New York, Cambridge University Press, 1996. p. 74-124.

Helpman, E. \& Krugman, P. R. Trade policy and market structure. Cambridge, The MIT Press, 1989. 
Hertel, T. W. (ed.). Global trade analysis: modeling and aplications. New York, Cambridge University Press, 1997.

\& Tsigas, M. E. Structure of Gtap. In: Hertel, T. W. (ed). Global trade analysis: modeling and applications. New York, Cambridge University Press, 1997.

Teixeira, E. C. Impact of the Uruguay round agreement and Mercosul on the Brazilian economy. Revista Brasileira de Economia. Rio de Janeiro, FGV, 52(3):441-62, jul./set. 1998.

Valverde, S. R. \& Teixeira, E. C. Impactos dos acordos da rodada do Uruguai, Mercosul e Nafta e da área de livre comércio das Américas (Alca) no comércio internacional. In: Vieira, W. \& Carvalho, F. (eds.). Mercosul: agronegócios e desenvolvimento econômico. Viçosa, Imprensa Universitária, 1997. p. 47-62. Varian, H. R. Microeconomia: princípios básicos - uma abordagem moderna. Rio de Janeiro, Campus, 1993. 